\title{
Effect of Growth Factors on Bovine Blastocyst Development in a Serum-Free Medium
}

\author{
By M. Shamsuddin
}

Department of Obstetrics and Gynaecology, Faculty of Veterınary Medicıne, Swedish Unıversity of Agricultural Sciences, Uppsala, Sweden.

\begin{abstract}
Shamsuddin, M.: Effect of growth factors on bovine blastocyst development in a serum-free medium. Acta vet. scand. 1994, 35, 141-147. - To investigate the effect of growth factors on pre-implantation development, bovine zygotes, produced by in vitro fertilization (IVF) of in vitro-matured (IVM) oocytes, were cultured in a serum-free medium to which the following growth factors were added one at a time: epidermal growth factor (EGF), acıdic fibroblast growth factor (a-FGF), insulın-lıke growth factor-II (IGF-II), platelet-derived growth factor from human platelets (PDGF), and platelet-derived growth factor-AB, human, recombinant (PDGF-AB). All growth factors were added at a dose of either 10 or $50 \mathrm{ng} / \mathrm{ml}$, except PDGF which was added at a dose of either 5 or $15 \mathrm{ng} / \mathrm{ml}$. The control medium was TCM 199 supplemented with sodium pyruvate $(0.25 \mathrm{mmol} / \mathrm{l})$, BSA $(10 \mathrm{mg} / \mathrm{ml})$, insulın $(5 \mu \mathrm{g} / \mathrm{ml})$, transferrın $(5 \mu \mathrm{g} / \mathrm{ml})$, and sodium selenite $(5 \mathrm{ng} / \mathrm{ml})$. Embryos were cultured for 8 days (day of insemination $=$ Day 0 ). The mean percentages of first cleavage on Day 2 varied from $67 \%$ to $86 \%$ and the differences between the 2 doses, or between the control and growth factortreated groups were not significant $(\mathrm{p} \geq 0.13)$. The effects of the two doses on subsequent development up to the blastocyst stage did not differ either $(p \geq 0.12)$. There was no stimulatory effect of any of the used exogenous growth factors on embryo development up to the morula or blastocyst stage on Day 7, or blastocyst stage on Day 8. Moreover, medium supplemented with PDGF had fewer blastocysts than the control $(\mathrm{p} \leq 0.03)$. The results indicate that growth factor supplementation may not necessarily increase the yield of blastocysts from bovine IVM-IVF oocytes in a serum-free medium.
\end{abstract}

embryo; IVM-IVF.

\section{Introduction}

There is convincing evidence that the transcription of embryonic genome takes place at the fourth cell cycle of bovine pre-implantation development (Barnes \& Eyestone 1990, Barnes \& First 1991). Embryos at this stage are more susceptible to adverse conditions, which may be prevailing during culture $i n v i$ tro, and are often arrested in their development (Barnes \& Eyestone 1990). However, with the refinement of techniques and avail- ability of highly purified chemicals and water, it is now possible to culture bovine one-cell embryos up to the blastocyst stage in commercially available tissue culture medium (Pinyopummintr \& Bavister 1991, Shamsuddin et al. 1993a, 1993b). Even protein-free medium supported the development of bovine IVMIVF embryos up to the blastocyst stage; however, serum supplementation increased the rate of blastulation (Pinyopummintr \& Bavister 1991, Takagi et al. 1991). The transcription 
of bovine embryonic genome at the fourth cell cycle was suggested to be regulated by certain growth factors (Larson et al. 1992a, 1992b, Thibodeaux et al. 1993). However, the expression of growth factor receptors was detected at all stages of bovine development up to the blastocyst (Schultz et al. 1992, Watson et al. 1992) indicating that growth factors may be generally involved in embryonic development instead of being specific to the fourth cell cycle. Exposure to exogenous growth factors was reported as increasing the yield of blastocysts, although the efficacy of growth factor-supplemented medium was compared with that of a poor efficacious control medium; the embryo development in the control medium was completely blocked either at the 8-cell stage (Larson et al. 1992b) or at the morula stage (Thibodeaux et al. 1993). Recently, a serum-free culture medium has been formulated which consistently supported a high rate of blastocyst development; the speed and frequency of blastocyst development (30\% of presumptive zygotes) were comparable to that of an oviduct cell co-culture system (Shamsuddin et al. 1993b). This serum-free medium, TCM 199 supplemented with bovine serum albumin (BSA), insulin, transferrin and selenium, has been used as a control in the present study to address the question whether growth factor supplementation can stimulate the bovine pre-implantation development up to blastocyst stage in culture.

\section{Material and methods}

One-cell bovine embryos were produced by in vitro fertilization (IVF) of in vitro-matured (IVM) oocytes. Briefly, cumulus-oocyte complexes (COC) were collected from small ovarian follicles $(<7 \mathrm{~mm})$ at slaughter and cultured for maturation in tissue culture medium 199 (TCM; Earle's salts with glutamine; Bio- chrom, Berlin, Germany; buffered with 26.2 $\mathrm{mmol} / \mathrm{l}$ sodium bicarbonate; $\mathrm{pH}$ 7.2) supplemented with oestrous cow serum (Shamsuddin et al. 1993c). After 24 to $25 \mathrm{~h}$ of culture, the expanded COC were inseminated with spermatozoa selected by a modified swim-up through a hyaluronic acid (HA; $1 \mathrm{mg} / \mathrm{ml}$ ) preparation (Shamsuddin \& Rodriguez-Martinez 1993). Ten to $15 \mathrm{COC}$ were co-incubated with about $50 \times 10^{3}$ spermatozoa in $50-\mu 1$ droplets of Fert-TALP (Parrish et al. 1988). The Fert-TALP was supplemented with BSA (6 $\mathrm{mg} / \mathrm{ml})$, heparin $(5.0 \mu \mathrm{g} / \mathrm{ml})$, D-penicillamine $(20 \mu \mathrm{mol} / \mathrm{l})$, hypotaurine $(10 \mu \mathrm{mol} / \mathrm{l})$ and epinephrine $(1 \mu \mathrm{mol} / \mathrm{l})$. The semen used was derived from a bull with proven high fertility. After 20 to $22 \mathrm{~h}$ of sperm-COC co-incubation, the presumptive zygotes (not differentiated from unfertilized oocytes) were denuded by repeatedly passing them through a small glass pipette. Ten to 20 zygotes were cultured in 50$\mu l$ droplets under paraffin oil of either control medium alone or of medium with one of the growth factors. The control medium was TCM supplemented with BSA $(10 \mathrm{mg} / \mathrm{ml})$, insulin $(5 \mu \mathrm{g} / \mathrm{ml})$, transferrin $(5 \mu \mathrm{g} / \mathrm{ml})$, sodium selenite $(5 \mathrm{ng} / \mathrm{ml})$, sodium pyruvate $(0.25$ $\mathrm{mmol} / \mathrm{l})$, sodium penicillin-G $(50 \mathrm{IU} / \mathrm{ml})$ and streptomycin sulphate $(50 \mu \mathrm{g} / \mathrm{ml})$. The growth factors were added one at a time to the control medium from frozen-thawed stock solutions. The final media were equilibrated for at least $2 \mathrm{~h}$ before use. Epidermal growth factor (EGF; \# E-1264) and acidic fibroblast growth factor (a-FGF; \# F-5267) were reconstituted in TCM supplemented with BSA $(10 \mathrm{mg} / \mathrm{ml})$ at $20 \mathrm{ng} / \mu \mathrm{l}$ and $1 \mathrm{ng} / \mathrm{ml}$, respectively. Insulinlike growth factor-II (IGF-II; \# I-2139) was reconstituted $(1 \mu \mathrm{g} / 10 \mu \mathrm{l})$ in $10 \mathrm{mmol} / \mathrm{l}$ acetic acid. Platelet-derived growth factor from human platelet (PDGF; \# P-8147) was reconstituted $(1 \mathrm{ng} / \mu \mathrm{l})$ in $1 \mathrm{M} / \mathrm{l}$ acetic acid. Platelet-derived growth factor- $\mathrm{AB}$, human, recombinant 
Table 1. Growth factor dose-effect on first cleavage of bovine zygotes and their subsequent development to morula (M) and blastocyst (BL) stages.

\begin{tabular}{|c|c|c|c|c|c|c|}
\hline \multirow{2}{*}{$\begin{array}{l}\text { Growth } \\
\text { factor }\end{array}$} & \multirow{2}{*}{$\begin{array}{l}\operatorname{Dose}^{a} \\
\mathrm{ng} / \mathrm{ml}\end{array}$} & \multirow{2}{*}{$\mathrm{n}$} & \multirow{2}{*}{$\frac{\text { Day } 2}{\% \text { cleaved }}$} & \multicolumn{2}{|c|}{ Day 7} & \multirow{2}{*}{$\begin{array}{r}\text { Day } 8 \\
\% \mathrm{~B} 1\end{array}$} \\
\hline & & & & $\% \mathrm{M}$ & $\% \mathrm{Bl}$ & \\
\hline \multirow[t]{2}{*}{ EGF } & 10 & 127 & $72.6 \pm 1.9$ & $19.9 \pm 3.8$ & $9.1 \pm 4.0$ & $24.1 \pm 6.4$ \\
\hline & 50 & 90 & $76.9 \pm 4.6$ & $21.1 \pm 5.7$ & $2.4 \pm 2.4$ & $14.2 \pm 4.3$ \\
\hline \multirow[t]{2}{*}{ a-FGF } & 10 & 106 & $85.6 \pm 4.9$ & $29.0 \pm 5.0$ & $8.5 \pm 1.4$ & $24.3 \pm 5.0$ \\
\hline & 50 & 117 & $85.9 \pm 4.3$ & $14.3 \pm 5.0$ & $10.3 \pm 3.7$ & $19.0 \pm 3.1$ \\
\hline \multirow[t]{2}{*}{ IGF-II } & 10 & 106 & $78.4 \pm 3.2$ & $22.7 \pm 4.5$ & $7.6 \pm 1.0$ & $16.0 \pm 3.2$ \\
\hline & 50 & 107 & $69.2 \pm 3.0$ & $22.4 \pm 4.1$ & $7.6 \pm 5.0$ & $18.7 \pm 1.0$ \\
\hline \multirow[t]{2}{*}{ PDGF } & 5 & 88 & $83.0 \pm 11.8$ & $20.5 \pm 4.3$ & $2.2 \pm 2.2$ & $5.9 \pm 3.0$ \\
\hline & 15 & 95 & $66.7 \pm 5.5$ & $22.1 \pm 4.5$ & $3.0 \pm 1.6$ & $9.0 \pm 2.9$ \\
\hline \multirow[t]{2}{*}{ PDGF-AB } & 10 & 98 & $75.5 \pm 10.0$ & $19.1 \pm 5.1$ & $2.1 \pm 1.1$ & $13.6 \pm 2.1$ \\
\hline & 50 & 109 & $78.9 \pm 2.1$ & $22.9 \pm 0.4$ & $6.3 \pm 2.1$ & $15.3 \pm 3.9$ \\
\hline
\end{tabular}

$\mathrm{n}=$ number of zygotes cultured; day of insemination = Day 0 ; values are mean $\pm \mathrm{SEM}$ of 3 observations; $\mathrm{a}=$ the difference between the effects of two doses did not differ significantly in any growth factor ( $\mathrm{p} \geq 0.12)$; EGF $=$ epidermal growth factor; a-FGF = fibroblast growth factor acidic; IGF-II = insulın-like growth factor-II; PDGF = platelet-derived growth factor; $\mathrm{PDGF}-\mathrm{AB}=$ platelet-derived growth factor $\mathrm{AB}$, human, recombinant.

(PDGF-AB; \# P-6684) was purchased in solution $(10 \mathrm{ng} / \mu \mathrm{l})$. All stock solutions were preserved at $-20^{\circ} \mathrm{C}$ until use, when further dilutions, if needed, were made with culture medium. All growth factors were added at a dose of either 10 or $50 \mathrm{ng} / \mathrm{ml}$, except PDGF which was added at a dose of either 5 or 15 $\mathrm{ng} / \mathrm{ml}$. Unless otherwise stated, the chemicals were purchased from Sigma, St. Louis, MO, USA. All zygotes from the sperm-COC co-incubation were pooled and divided equally to different treatments; at least 2 treatments were run in parallel. The experiment includes 3 replicates for every dose of a growth factor and 6 replicates for control. The effects of different treatments were evaluated by the proportions of embryos that cleaved on Day 2, by the proportions of morulae and blastocysts on Day 7, and by the proportions of blastocysts on Day 8 (day of insemination = Day 0$)$. All cultures and equilibrations were performed at $39^{\circ} \mathrm{C}$ and $5 \% \mathrm{CO}_{2}$ in humidified air.
The effects of the growth factor supplementation on embryo development were determined by the Kruskal-Wallis test (Proc NPAR1WAY; SAS Institute Inc. 1987), with comparisons being conducted first between the 2 doses of each growth factor and then between the control and individual growth factor-treated groups.

\section{Results}

In total, 1043 presumptive zygotes were cultured after supplementing the medium with one of 5 growth factors at either of 2 doses (Table 1). An additional 206 zygotes were cultured in the control medium (Table 2). The mean percentages of embryos that cleaved at least once varied from $67 \%$ to $86 \%$. The effects of the 2 doses of growth factors on embryo development up to the blastocyst stage did not differ significantly, except a fewer blastocysts in $50 \mathrm{ng} / \mathrm{ml}$ than in $10 \mathrm{ng} / \mathrm{ml}$ of 
Table 2. Effects of growth factor supplementation on first cleavage and subsequent development of bovine embryos up to blastocyst stage (abbreviations as in Table 1 ).

\begin{tabular}{|c|c|c|c|c|c|}
\hline \multirow{2}{*}{ Treatment } & \multirow{2}{*}{$\mathrm{n}$} & \multirow{2}{*}{$\frac{\text { Day } 2}{\% \text { cleaved }}$} & \multicolumn{2}{|c|}{ Day 7} & \multirow{2}{*}{$\begin{array}{r}\text { Day } 8 \\
\% \mathrm{Bl}\end{array}$} \\
\hline & & & $\% \mathrm{M}$ & $\% \mathrm{Bl}$ & \\
\hline EGF & 217 & $74.7 \pm 2.4$ & $20.5 \pm 3.1$ & $5.7 \pm 2.6$ & $19.2 \pm 4.1$ \\
\hline a-FGF & 223 & $85.7 \pm 2.9$ & $21.6 \pm 4.6$ & $9.4 \pm 1.8$ & $21.7 \pm 2.9$ \\
\hline IGF-II & 213 & $73.8 \pm 2.8$ & $22.6 \pm 2.7$ & $7.6 \pm 2.3$ & $17.3 \pm 1.6$ \\
\hline PDGF & 183 & $74.8 \pm 6.9$ & $21.4 \pm 2.8$ & $2.6 \pm 1.2^{\mathrm{a}}$ & $7.5 \pm 2.0^{\mathrm{a}}$ \\
\hline PDGF-AB & 207 & $77.2 \pm 4.6$ & $21.0 \pm 2.4$ & $4.2 \pm 1.4$ & $14.4 \pm 2.0$ \\
\hline Control & 206 & $81.3 \pm 2.5$ & $20.7 \pm 3.4$ & $10.5 \pm 4.0$ & $22.2 \pm 3.7$ \\
\hline
\end{tabular}

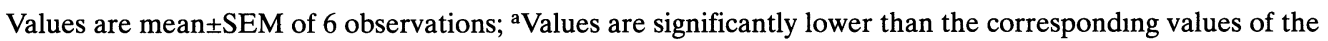
control $(\mathrm{p} \leq 0.03)$.

EGF ( $\mathrm{p} \geq 0.13$ ). Therefore, data on embryo development under the 2 doses of each growth factor were pooled and compared with data on the control medium.

Supplementation of culture medium with EGF, a-FGF or IGF-II did not have any significant positive or negative effect on the yield of morulae and blastocysts on Day 7, and blastocysts on Day 8 (Table 2; $\mathrm{p} \geq 0.26$ ). However, the percentage of blastocysts in PDGF-supplemented medium was significantly lower than that in control medium both on Day 7 and on Day $8(\mathrm{p} \leq 0.03)$. Medium supplemented with PDGF-AB also tended to have fewer blastocysts than the control medium $(\mathrm{p} \leq 0.09)$.

\section{Discussion}

The effect of several mitogenic growth factors on the bovine pre-implantation development was studied using a serum-free culture medium as control (Shamsuddin et al. 1993b). The efficacy of the control medium has been consistently higher than that of controls used in several recent studies where growth factors were tested (Larson et al. 1992a, 1992b, Flood et al. 1993, Thibodeaux et al. 1993). Under the prevailing conditions, the results of the present study show that addition of commercially available growth factors failed to stimulate the bovine embryo development in culture. In accordance with the results of the present study, EGF did not stimulate the chronological development of bovine embryos up to the blastocyst stage (Takagi et al. 1991, Keefer 1992, Flood et al. 1993). However, EGF-treated blastocysts tended to hatch at a higher rate (Keefer 1992, Flood et al. 1993). In mouse embryos, EGF stimulated the mitotic and hatching rates when embryos were cultured singly in micro-drops (Parla \& Dey 1990). This effect was undetectable when embryos were cultured in a group (Wood \& Kaye 1989, Paria \& Dey 1990). It was therefore speculated that when cultured in a group, growth factors produced by one embryo may stimulate development in the fellow embryos; thereby limiting the effect of the exogenous growth factors (Paria \& Dey 1990). Nevertheless, in monovulatory animals a paracrine growth factor action between embryos in vivo may be unlikely.

Acidic-FGF did not show any effect on the cultured bovine embryos in the present study. Accordingly, supplementation of culture me- 
dium with basic-FGF did not lead to any significant change in the frequency of blastocyst development in the bovine (Larson et al. 1992b, Flood et al. 1993). The a-FGF is homologous to the b-FGF regarding the sequence and number of amino acids (Thomas et al. 1987) and both were equally mitogenic to epithelial cell lines (Simmen et al. 1993). Larson et al. (1992b) reported a synergistic effect of bFGF and transforming growth factor- $\beta$ on the development of embryos from the 8-cell stage to the 16-cell stage; however, the effect was not detectable when development up to the blastocyst stage was considered.

In the present study, insulin-like growth factor-II did not influence the bovine blastocyst development, which is consistent with the results of Flood et al. (1993). Receptors for insulin, IGF-I and IGF-II have been reported from pre-implantation embryos from bovine and other species (Kaye et al. 1992, Schultz et al. 1992, Watson et al. 1992). However, the embryotrophic effects of IGFs in culture are controversial (Paria \& Dey 1990, Harvey \& Kaye 1992). Although growth factors of the insulin family share many common characteristics, the sources of their origin seem to differ; insulin and IGF-I are maternally derived while the most important source of IGF-II seems to be the paternal allele (see Kaye et al. 1992, Schofield \& Engstrom 1992, for review). It is likely that IGF-II serves an autoregulatory function in embryos that receive a normal functioning ligand allele from the father, and thereby the effect of exogenously supplied IGF-II was limited. Using a mutant mouse model, Baker et al. (1993) have demonstrated a slower embryonic and postnatal growth rate in IGF-II deficient mice.

Natural PDGF from human platelets has significantly reduced the development of blastocysts in culture compared to the control, as found in the present study. This is consistent with the result of Larson et al. (1992a). Using the same commercial PDGF as used in the present study, Flood et al. (1993) reported a yield of about $12 \%$ blastocysts; the values did not differ from the control. A stimulatory effect of PDGF was found on the fourth cell cycle of cultured bovine embryos (Larson et al. 1992a, Thibodeaux et al. 1993); however, the two studies showed contrasting effects of PDGF on the yield of blastocysts. In the present study, the percentage of morulae did not differ between control and PDGF-treated groups, indicating that the transcription of embryonic genome at the fourth cell cycle of bovine development may not be dependent upon PDGF.

It is not clearly understood why PDGF reduces blastocyst development. Two questions can be raised: 1) since natural PDGF was dissolved in a highly acidic solution, there is a risk that the $\mathrm{pH}$ of the culture medium was lowered by the stock solution, and thereby the activities of other essential compounds were reduced; 2) natural PDGF might have carried contaminants which were detrimental to embryos. In order to address those questions, a highly purified, recombinant PDGF containing a heterodimer similar to that in the natural ones (PDGF-AB) was included in the present study. The data on PDGF-AB also indicated a tendency for a reduced yield of blastocysts, compared to the control. The PDGF, a serum mitogen with major pleiotropic effects, is involved in autocrine or paracrine stimulation of cell growth, provided that specific receptors are present in the responsive cells. The presence of $\alpha$ and $\beta$-type receptors for PDGF and of PDGF-A has been determined immunocytochemically in the trophoblast of elongated, preimplantation bovine embryos (Rodriguez-Martinez et al. 1989, Persson et al. 1991). Although the expression of PDGF receptors has also been shown in all 
earlier stages of bovine development up to blastocyst in a serum-containing medium with oviduct cells (Watson et al. 1992), a better understanding of PDGF-receptor behaviour under more defined conditions is necessary to answer whether the effects of this polypeptide are blocked by other chemicals or vice versa. The lack of positive effect of growth factors in culture does not necessarily mean that growth factors are not involved in the bovine pre-implantation development in vivo. The concentration, half-life, physical and chemical properties of stock solutions and culture medium, storage period and temperature, transportation and sources all can affect the potency of a biological product. In the present study, each growth factor was used in 2 doses. The outcome of the 2 doses did not differ significantly, except for a tendency of the higher dose of EGF $(50 \mathrm{ng} / \mathrm{ml})$ to reduce blastocyst yield. Supplementation with other doses or several growth factors together may show stimulatory effect on embryo development but this remains to be determined.

\section{Acknowledgements}

The author thanks Professor Heriberto RodriguezMartınez and Dr. Bırgitta Larsson for critically revısing the manuscript and for translating the summary into the Swedısh language, and Ms. All Colbing and Ms Gunilla Lekselius for technical assistance. Frozen semen was generously supplied by Elitsemin, Eskilstuna, Sweden. The project received financial support from the Council of Ministers of the Nordic Countries and the Swedish Council for Forestry and Agricultural Research.

\section{References}

Baker J, Liu J-P, Robertson EJ, Efstratiadis A: Role of insulin-like growth factors in embryonic and postnatal growth. Cell 1993, 75, 73-82.

Barnes FL, Eyestone WH: Early cleavage and the maternal zygotic transition in bovine embryos. Theriogenology 1990, 33, 141-152.

Barnes FL, First NL. Embryonic transcription in in vitro cultured bovine embryos. Molec. Reprod. Dev. 1991, 29, 117-123.
Flood MR, Gage TL, Bunch TD: Effect of various growth-promoting factors on preimplantation bovine embryo development in vitro. Theriogenology 1993, 39, 823-833.

Harvey $M B$, Kaye $P L$ : Insulin-like growth factor-1 stimulates growth of mouse preimplantation embryos in vitro. Molec. Reprod. Dev. 1992, 31, 195199.

Kaye PL, Bell KL, Beebe LFS, Dunglison GF, Gardner $H G$, Harvey $M B$ : Insulin and the insulin-like growth factors (IGFs) in preimplantation development. Reprod. Fertil. Dev. 1992, 4, 373-386.

Keefer CL: Development of in vitro produced bovine embryos cultured individually in a simple medium: effects of EGF and TGF $\beta 1$. Theriogenology 1992, 37, 236.

Larson RC, Ignotz GG, Currie WB. Platelet derived growth factor (PDGF) stimulates development of bovine embryos during the fourth cell cycle. Development 1992a, 115, 821-826.

Larson RC, Ignotz GG, Curre WB. Transforming growth factor $\beta$ and basic fibroblast growth factor synergistically promote early bovine embryo development during the fourth cell cycle. Molec. Reprod. Dev. 1992b, 33, 432-435.

Paria BC, Dey SK: Preimplantation embryo development in vitro: cooperative interactions among embryos and role of growth factors. Proc. Natl. Acad. Sc1. USA. 1990, 87, 4756-4760.

Parrish JJ, Susko-Parrish J, Winer MA, First NL. Capacitation of bovine sperm by heparin. Biol. Reprod. 1988, 38, 1171-1180.

Persson E, Hurst M, Rodriguez-Martinez H, Albihn $A$, Heldin $C H$. Immunocytochemical localization of PDGF receptors in the elongating bovine and porcine blastocyst. A.R.T.A. 1991, 2, 171172.

Pinyopummintr T, Bavister BD: In vitro-matured/ın vitro-fertılized bovine oocytes can develop into morulae/blastocyst in chemically defined, protein-free culture media. Biol. Reprod. 1991, 45, 736-742.

Rodriguez-Martinez H, Albihn A, Claesson-Welsh L, Heldin $C$ - $H$, Jansson $\AA$, Ekwall $H$, Gustafsson $H$, Larsson $K$ : Immunocytochemical localization of PDGF-receptors in the elongating bovine blastocyst. J. Ultrastr. Molec. Struct. Res. 1989, 102, 299.

SAS Institute Inc. $\cdot$ SAS/STAT ${ }^{\mathrm{TM}}$ Guide for Personal Computers. Ed. 6; Cary, NC, 1987.

Schofield PN, Engstrom W: Insulın-like growth factors in human cancer. In: Schofield PN (ed): The 
Insulin-like Growth Factors: Structure and Biological Functions. Oxford University Press, Oxford, 1992, 240-257.

Schultz GA, Hogan A, Watson AJ, Smith RM, Heyner S: Insulin, insulin-like growth factors and glucose transporters: temporal pattern of gene expression in early murine and bovine embryos. Reprod. Fertil. Dev. 1992, 4, 361-371.

Shamsuddin M, Larsson B, Gustafsson H, Rodriguez-Martinez $H$ : In vitro development up to hatching of bovine in vitro-matured and fert1lized oocytes with or without support from somatic cells. Theriogenology 1993a, 39, 10671079.

Shamsuddin M, Larsson B, Rodriguez-Martinez $H$. Culture of bovine IVM/IVF embryos up to blastocyst stage in defined medium using insulin, transferrin and selenium or growth factors. Reprod. Dom. Anim. 1993b, 28, 209-210.

Shamsuddin M, Larsson B, Rodriguez-Martınez $H$ : Maturation-related changes in bovine oocytes under different culture conditions. Anım. Reprod. Sci. 1993c, 31, 49-60.

Shamsuddin M, Rodriguez-Martinez H: Use of hyaluronic acid-selected spermatozoa for in vitro fertillzation in the bovine. J. Reprod. Fertil. Abstr Ser. 1993, 11, 66.

Simmen RCM, Ko Y, Simmen FA: Insulın-like growth factors and blastocyst development. Theriogenology 1993, 39, 163-175.

Takagı Y, Morı K, Tomızawa M, Takahashı T, Sugawara S, Masakl J: Development of bovine oocytes matured, fertilized and cultured in a serumfree, chemically defined medium. Theriogenology 1991, 35, 1197-1207.

Thibodeaux JK, Del Vecchio RP, Hansel W: Role of platelet-derived growth factor in development of in vitro matured and in vitro fertilized bovine embryos. J. Reprod. Fertil. 1993, 98, 61-66.

Thomas KA, Gimenez-Gallego G, Rios-Candelore $M$, DiSalvo J: Primary structure and mitogenic and angiogenic activities of brain-derived acidic fibroblast growth factors. J. Protein Chem. 1987, 6, 163-171.

Watson AJ, Hogan A, Hahnel A, Wiemer KE, Schultz $G A$ : Expression of growth factor ligand and receptor genes in the preimplantation bovine embryo. Molec. Reprod. Dev. 1992, 31, 8795.

Wood SA, Kaye PL: Effects of epidermal growth factor on preimplantation mouse embryos. J. Reprod. Fertil. 1989, 85, 575-582.

\section{Sammanfattning \\ Effekten av tillvaxtfaktorer på notkreatursembryons utveckling till blastocyster $\mathrm{l}$ ett serum-fritt medium.}

For att undersóka effekten av tillvaxtfaktorer på embryoutvecklingen fore implantationen användes notkreatursembryon i en-cellstadiet, framtagna genom in vitro befruktning (IVF) av in vitro mognade (IVM) oocyter. Embryonerna odlades 1 ett serumfritt medium till vilket en av foljande tillvaxtfaktorer tillsattes: epidermal growth factor (EGF), acidic fibroblast growth factor (a-FGF), insulin-like growth factor-II (IGF-II), platelet-derived growth factor från humana trombocyter (PDGF) och human rekombinant platelet-derived growth factor-AB (PDGF-AB). Alla tlllvaxtfaktorer tillsattes i doser av 10 eller $50 \mathrm{ng} / \mathrm{ml}$, utom PDGF som tillsattes $i$ antıngen 5 eller $15 \mathrm{ng} / \mathrm{ml}$. Som kontrollmedium anvandes TCM 199 till vilket tillsatts natruumpyruvate $(0.25 \mathrm{mmol} / \mathrm{l}), \mathrm{BSA}(10 \mathrm{mg} / \mathrm{ml})$, insulın $(5$ $\mu \mathrm{g} / \mathrm{ml})$, transferrın $(5 \mu \mathrm{g} / \mathrm{ml})$ och natrium- selenit (5 $\mathrm{ng} / \mathrm{ml}$ ). Embryonerna odlades vid $39^{\circ} \mathrm{C}$ och $5 \% \mathrm{CO}_{2}$ i fuktmattad luft under 8 dagar (dag $0=$ dagen for befruktningen). Den genomsnittliga andelen oocyter som genomgått forsta delningen på dag 2 varierade från $67 \%$ tıll $86 \%$. Skıllnaderna mellan de 2 doserna eller mellan kontrollgrupp och behandlingsgrupper var inte signifikant $(p \geq 0.13)$. Det var inte heller någon skillnad $\mathrm{i}$ effekt av de två doserna på utvecklingen till blastocyststadiet $(p \geq 0.12)$. Ingen av de exogent tillforda tillvàxtfaktorerna hade någon stimulerande effekt på embryoutvecklingen till morula eller blastocyststadiet på dag 7 eller till blastocyststadiet på dag 8. Färre blastocyster utvecklades 1 medium med tillsats av PDGF an 1 kontrollmediet $(\mathrm{p} \leq 0.03)$. Resultaten indikerar att tillsattande av tillvaxtfaktorer till ett serum-fritt medium inte stimulerar utvecklingen av IVM-IVF oocyter till blastocyster.

(Recelved September 21, 1993; accepted December 22, 1993).

Reprints may be requested from: M. Shamsuddin, Department of Obstetrics \& Gynaecology, Swedish University of Agricultural Sciences, S-750 07 Uppsala, Sweden. 
